\title{
Book Review: Climate Change and Agriculture in India: Impact and Adaptations
}

\author{
Prithvi Ram Bommaraboyina ${ }^{1 *}$, John Daniel ${ }^{2}$ and Kumar Abbhishek ${ }^{3}$ \\ ${ }^{1}$ South Asian Consortium for Interdisciplinary Water Resources Studies, Hyderabad, India, ${ }^{2}$ ICRISAT Development Center, \\ International Crop Research Institute for Semi-Arid Tropics, Patancheru, India, ${ }^{3}$ The Centre for Oceans, Rivers, Atmosphere \\ and Land Sciences (CORAL) at Indian Institute of Technology, Kharagpur, India
}

Keywords: greenhouse gases, crop models, social implications, precipitation, climate resilient agriculture

A Book Review on

Climate Change and Agriculture in India: Impact and Adaptations

Syed Sheraz Mahdi (Srinagar: Springer), 2018, 262 pages, ISBN: 978-3-319-90085-8 (eBook-pdf)

Climatic change is a long term abutment weather condition specifically concerned with temperature and precipitation. This climate change may be the result of natural calamities such as volcanic eruptions or anthropogenic activities like forest fires, greenhouse gas emission, and land-use changes (Reddy, 2015). The average surface temperature of the plant has been reduced by $0.89^{\circ} \mathrm{C}$ since 1901 (IPCC AR5, 2014). Further, the mean global temperature is anticipated to increases by another 1.5 to $2^{\circ} \mathrm{C}$ by the end of the twenty-first century (IPCC AR5, 2014). Since 1901 planet earth experienced increased precipitation despite a reduced number of rainy days which shows that there are an increased intensity and spatial variability of rainfall (IPCC AR5, 2014). Thus, climate change is perceived to bring in increased temperature attended precipitation patterns with increased frequency and severe extreme weather events. It is very much evident that climate change has a severe impact on global food production influencing both demand and supply of food grains, globally (Srinivasarao et al., 2018) under such conditions the program of sustainable development goals will continuously slow down, affecting the communities immensely. Besides this about 85\% of Indian farmers and marginal and small landholders (Agriculturalcensus, 2011 http://agsccences.nic.in) and about $60 \%$ of the net sown area under rainfed agriculture. This makes India vulnerable to climate change considerably effecting the cropping system, livestock, fisheries, poultry, soil, pest, and diseases. Climate change would have a serious impact on Indian agriculture in the coming years which would negatively impact some important crops that would lead the country to food insecurity. The present trend and scenario are evident that without an efficient measure it would be very difficult to meet agro- demand of the country. Thus, efficient measures of adaption and mitigation are required.

In the context, this book "Climate change and agriculture in India: Impacts and Adaptations." edited by Mahdi (2019) is an attempt to provide a basic understanding of climate change showcasing the specific sectorial research trend in the country's important cereals crops, paddy and wheat, inland fisheries and temperate region horticultural crops. The chapters discuss the different mitigation strategies for climate change impacts, considering biotic and abiotic stress holistically, relating them to the present concept of changing climate. The book provides perceptual discussions of the climatic change and resilient agricultural systems limited to temperate and sub-tropical regions of the country. This is a book for students to understand the present trends of climate change mitigation interventions.

Bommaraboyina PR, Daniel J and Abbhishek K (2020) Book Review: Climate Change and Agriculture in India: Impact and Adaptations. Front. Clim. 2:576004 doi: 10.3389/fclim.2020.576004 
This book deals with the particularly view such as (i) Evidences for climate change in which the authors discusses about projected temperature and precipitation in the scenario of erosion specifically for paddy and wheat cultivation in India, Condition of country's crop production under the effects of El-nino and La-nino events, Effect of changing climate or temperature fruit cultivation in the Kashmir valley, Global scenario of climate change and Inland open fisheries in Indian scenarios, the future projections and present scenario of climate change in cold arid regions of India (ii) Mapping and modeling studies like simulation modeling and its impacts and variability's of climate change on Indian agriculture, investigation on global climate models (GCM'S) and crop model capabilities to provide appropriate decision making information, spatiotemporal mapping of agricultural dynamics in association with floods and their impacts in the state of Bihar specifically (iii) Experimental and analytical assessment studies like assessment of bio priming mediated nutrient use efficiency for climate resilient agriculture, the analytical quantification of socio-economic and ecological implication by using accretion of data and modulation, environmentally viable by engineering estimates through biogeo-chemical cyclic lens were part of the book chapters (iv) Atmospheric stress management in crops by adaptation and interventions, Tropical fruit production systems in the impact of climate change and potential mitigation strategies, Plant breeders style of strategies for mitigating climate change, Minimizing the vulnerabilities to climate change in the state of Bihar using smart agriculture options, harnessing the benefits of nano- technology in the scenarios of climate change, Harnessing the under-utilized crops into the mainstreaming agriculture for sustainable future, The micro- weather based information system for efficient

\section{REFERENCES}

Agriculturalcensus (2011). Available online at: https://agcensus.nic.in/document/ agcensus2010/completereport.pdf

IPCC AR5 (2014). Climate Change 2014: Synthesis Report. Contribution of Working Groups I, II and III to the Fifth Assessment Report of the Intergovernmental Panel on Climate Change, eds Core Writing Team, R. K. Pachauri, and L. A. Meyer. Geneva: IPCC, 151.

Mahdi, S. S. (ed.). (2019). Climate Change and Agriculture in India: Impact and Adaptation. Srinagar: Springer.

Reddy, P. P. (2015). Climate Resilient Agriculture for Ensuring Food Security, Vol. 373. New Delhi: Springer.

Srinivasarao, Ch., Shanker, A., and Chanker, C. (2018). Climate Resilient Agriculture-Strategies and Perspectives. Hyderabad: Intech Open, 181. risk management in the Indian agriculture, Sustainable Indian agriculture by adaptation and mitigation of climate change and Greenhouse gas emission from selective cropping patterns for the neighboring country "Bangladesh" were incorporated in the present book.

The editor represented only a part of the proposed title "Climate Change and agriculture in India," the book has a dearth of information regarding the diverse Indian agricultural sector as a whole. The components of great importance like livestock and poultry which strengthens the agricultural sector in the Indian economy in terms of providing protein and nutritional security, income, and foreign exchange remained unaddressed. Similarly, the role of soil health management, agro-forestry, pest, and disease management which is the key to agricultural sustainability is not discussed in the book. Agriculture is also a contributor to greenhouse gases (GHG's) emissions and global warming thus it is important to account for these emissions from the Indian Agro sector. To achieve this, we need to adopt strategies like Integrated Nutrient Management (INM) and site-specific nutrient management, neither GHG's contribution from the India agriculture nor its mitigation strategies are discussed and representation of the chapter on GHG's of the neighboring country Bangladesh but missed to correlated to the context of the book. The book has gaps for future discussion on, How is Climate change affecting Indian agriculture?

\section{AUTHOR CONTRIBUTIONS}

All authors listed have made a substantial, direct and intellectual contribution to the work, and approved it for publication.

Conflict of Interest: The authors declare that the research was conducted in the absence of any commercial or financial relationships that could be construed as a potential conflict of interest.

Copyright (C) 2020 Bommaraboyina, Daniel and Abbhishek. This is an open-access article distributed under the terms of the Creative Commons Attribution License (CC $B Y)$. The use, distribution or reproduction in other forums is permitted, provided the original author(s) and the copyright owner(s) are credited and that the original publication in this journal is cited, in accordance with accepted academic practice. No use, distribution or reproduction is permitted which does not comply with these terms. 